\title{
KINETIC-CATALYTIC DETERMINATION OF ULTRAMICRO AMOUNTS OF Co(II) USING 4-HYDROXYCOUMARINE- PERMANGANATE REDOX REACTION
}

\author{
DRAGANA SEJMANOVIĆ ${ }^{*}$, RUŽICA MICIĆ ${ }^{1}$, RANKO SIMONOVIĆ ${ }^{1}$ \\ ${ }^{1}$ Faculty of Natural Sciences and Mathematics, University of Priština, Kosovska Mitrovica, Serbia
}

\begin{abstract}
Determination of Co(II) based on its catalytic effect on the reaction between 4-hydroxycoumarine and potassium permanganate, in the presence of acetate buffer was described. The method development includes optimization of the reagent concentration and temperature. Absorbance of potassium permanganate was measured at $525 \mathrm{~nm}$. The calibration curve was linear in the range of $0.5-4 \mathrm{ng} / \mathrm{cm}^{3}$ of $\mathrm{Co}$ (II). The relative standard deviation was in the interval 6.25-2.60\% of the concentration range of $0.6-3 \mathrm{ng} / \mathrm{cm}^{3} \mathrm{Co}(\mathrm{II})$, respectively. The interference effects of foreign ions were determined for the assessment of the selectivity of the method. The proposed method was found to have excellent sensitivity, relatively good selectivity and simplicity.
\end{abstract}

Keywords: cobalt(II), kinetic method, 4-hydroxycoumarine.

\section{INTRODUCTION}

Cobalt is an essential element in trace amounts for humans and animal as an integral part of the vitamin $\mathrm{B}_{12}$ complex; also necessary for the synthesis of a number of hormones, neurotransmitters and other compounds (Medina-Escriche et al., 1987). However, in higher concentrations cobalt is toxic to humans, animals and plants. The essentiality of cobalt has also been demonstrated in the environment elsewhere: as a micronutrient for some blue-green algae, required for nitrogenfixation in legumes, in growth enhancement of some terrestrial plants at low concentration (Kiran et al., 2012). Cobalt is used as a pigment in glass, ceramics and paints; as a catalyst for the petroleum industry and in batteries. Cobalt is also found in low concentration in marine waters.

Although a number of methods are available for the determination of cobalt ions such as flame atomic absorption spectroscopy (FAAS), graphite furnace atomic absorption spectroscopy (GFAAS) (Jiang et al., 2008), inductively-coupled plasma optical emission spectroscopy (ICP-OES) (Mikula et al., 2007; Suleiman et al., 2007), inductively-coupled plasma coupled with mass spectrometry (ICP-MS) (Juvonen et al., 2002). These modern sophisticated sensitive methods are relatively expensive and require time for sample preparation, also can be applied after preliminary treatments such as preconcentration and extraction. Catalytic-kinetic methods have some advantages, including high sensitivity, short analysis time and minimum, low cost and easy available instruments (Mitić et al., 2009; Li, 1998; Safavi et al., 2002). Hence, due to these reasons simple colorimetric methods are still popular. Kinetic methods determined $\mathrm{Co}$ (II) as the catalyst of various reactions of oxidation with hydrogen peroxide or $\mathrm{KIO}_{4}$ as the oxidant and

\footnotetext{
* Corresponding author: dragana.sejmanovic@pr.ac.rs CHEMISTRY
}

different organic, aromatic oxy-compound, as the reductant. Different sensitive analytical methods including extractive spectrophotometry (Kamble et al., 2011), non-extractive derivative spectrophotometry, cloud-point extraction (Safavi et al., 2004), electro chemical detection (ECE) coupled with liquid chromatography (Suleiman et al., 2007) and kinetic spectrophotometric methods have been recognized as offering a valuable approach for the trace analysis (Bahram et al., 2012; Naseri et al., 2011; Wang et al., 2003; Ghasemi et al., 1998) of cobalt.

The aim of this study was to develop a simple trace kineticspectrophotometric method for the determination of cobalt(II) ions. An indicator reaction (oxidation 4-hydroxycoumarine by $\mathrm{KMnO}_{4}$ ) has not previously been used for the kinetic determination of trace amounts of $\mathrm{Co}$ (II). The method is based on the catalytic effect of $\mathrm{Co}$ (II) on the oxidation 4hydroxycoumarine by $\mathrm{KMnO}_{4}$ in acetate buffer solution at $\mathrm{pH}=3.8$, at $25 \pm 0.1^{\circ} \mathrm{C}$. Diminution of the colour intensity of the oxidant $\left(\mathrm{KMnO}_{4}\right)$ was followed spectrophotometrically as the change of absorbance(A) in time (t).

\section{EXPERIMENTAL}

\section{Reagents and Solutions}

Analytical grade reagents, deionized water and polyethylene vessels were used throughout the study. A solution of $\mathrm{KMnO}_{4}$ was prepared from an ampoule produced by „Merck" by dissolving in a volumetric flask. Before the experiment, the concentration of the solution was checked spectrophotometrically (at $525 \mathrm{~nm}$ ). The solution of $\mathrm{KMnO}_{4}$ was saved in a dark reagent flask.

A $1.25 \times 10^{-3} \mathrm{~mol} / \mathrm{dm}^{3}$ solution of 4-hydroxycoumarine (in the text we have marked as 4-OHcoum.) was prepared by dissolving the appropriate amount of the solid compound. To improve its solubility, an equivalent amount of $\mathrm{NaOH}$ was 
added. A stock solution of $\mathrm{Co}$ (II) (1000 ppm) was prepared by dissolving $1 \mathrm{~g}$ of metal of cobalt analytical grade in $50 \mathrm{~cm}^{3}$ of $\mathrm{HCl}(1: 1)$ and diluted to $1 \mathrm{dm}^{3}$.

The exact concentration was determined electrogravimetrically from a more concentrated solution. A acetate buffer solution was prepared from $0.2 \mathrm{~mol} / \mathrm{dm}^{3}$ $\mathrm{CH}_{3} \mathrm{COOH}$ and $1 \mathrm{~mol} / \mathrm{dm}^{3} \mathrm{NaOH}$ solutions.

\section{Apparatus}

A MA9524 SPECOL 221 (Carl Zeiss-Iskra) spectrophotometer equipped with thermostat system was used for spectrophotometric measurements. A cell of path-length $10 \mathrm{~mm}$, were used. The $\mathrm{pH}$ was measured by means of a radiometer (PHM 29b pH-meter) equipped with a GK $2311 \mathrm{C}$ combined electrode. All solutions were kept in a thermostatic water-bath (,Sutjeska“, type 10 ) at $25 \pm 1{ }^{\circ} \mathrm{C}$ before beginning the reaction.

\section{Procedure}

The method continual variations were performed, so the concentrations of the examined reactant was varied in given interval, while others were kept constant.

The selected volumes of the reactants were put into a 10 $\mathrm{cm}^{3}$ standard flask in the following order: 4-hydroxycoumarine, acetate buffer, standard solution of $\mathrm{Co}$ (II) and water to make up exactly to the predetermined volume. The flask was kept in a thermostat for 10 min., and then the solution was made up to the mark with $\mathrm{KMnO}_{4}$ and water. The content of the flask was mixed well. The cell of the photometer was rinsed well and filled with the prepared solution. Time changes of the abcorbance, $\mathrm{dA} / \mathrm{dt}$, were measured every 30 s over a period of 5-6 min. during the reaction. The $\mathrm{dA} / \mathrm{dt}$ was proportional to the reaction rate $(\mathrm{dc} / \mathrm{dt})$ expressed as:

$$
\mathrm{dA} / \mathrm{dt}=\varepsilon \times 1 \times \mathrm{dc} / \mathrm{dt}=\tan \alpha
$$

where $\varepsilon$ is molar absorptivity, 1 the cell path-length, $c$ the concentration of the $\mathrm{KMnO}_{4}$, tan $\alpha$ the slope of the linear part of the A against t.

The initial concentrations of the reagent solutions after the dilution to $10 \mathrm{~cm}^{3}$ were: $5 \times 10^{-5}-2.5 \times 10^{-4} \mathrm{~mol} / \mathrm{dm}^{3}$ of 4 hydroxycoumarine, $4 \times 10^{-5}-3.2 \times 10^{-4} \mathrm{~mol} / \mathrm{dm}^{3} \quad \mathrm{KMnO}_{4}, \quad 0.5-4$ $\mathrm{ng} / \mathrm{cm}^{3} \mathrm{Co}(\mathrm{II})$. An unknown concentration of cobalt(II) was calculated from the equation (1).

\section{RESULTS AND DISCUSSION}

The exact mechanism of reaction and the nature of reaction products were not the main interest of our investigation, but only important analytical meaning. As the reaction progresses, the initial red color of the solution fades and the colorless reaction product forms. All spectrophotometric measurements were performed at the wavelength of the absorption maximum of $\mathrm{KMnO}_{4}$ in acetate buffer $(525 \mathrm{~nm})$.

\section{Effect of the experimental conditions}

For finding the optimum experimental conditions, the effect of $\mathrm{pH}$, potassium permanganate concentration, concentration of 4-hydroxycoumarine and concentration of acetate buffer, on the reaction rate were studied by differential variant of the tangent method. The differential variant of the tangent method was used for processing the kinetic data, because there is a linear relation between the abcorbance and time during the first 2-5 min. after mixing.

Keeping concentrations of the other reactants constant we studied the effect of $\mathrm{pH}$ on the rates of catalytic and non-catalytic reactions in the range of 3.2-5.0.

The results are presented in Fig. 1. Figure 1 shows that there is complicated relationship between the $\mathrm{pH}$ and the catalytic and non-catalytic reaction rate in the studied $\mathrm{pH}$ range. The best results were obtained for the value $\mathrm{pH}$ of 3.80, and this value was selected as the optimum $\mathrm{pH}$ value for the system studied. At lower $\mathrm{pH}$ values, drastically increases the rate of reactions, and error in the determination of $\operatorname{tg} \alpha$ becomes larger.

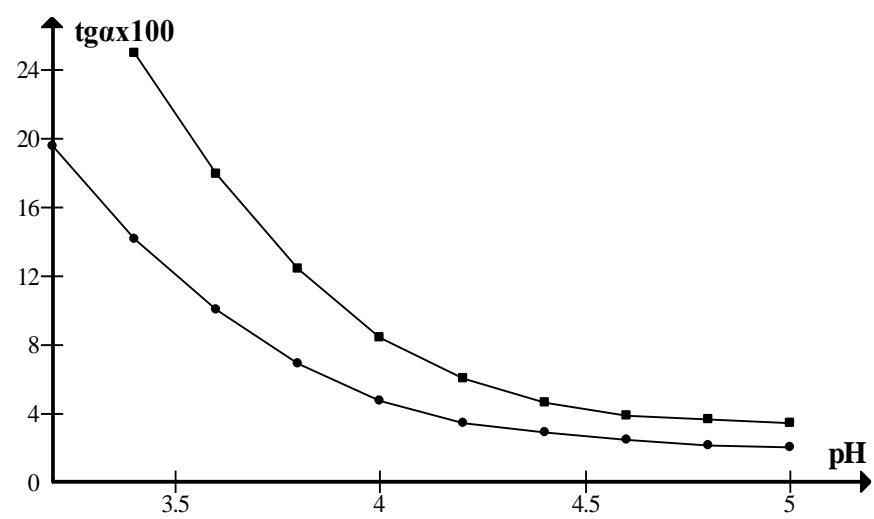

Figure 1.Effect of $\mathrm{pH}$ on determination of $\mathrm{Co}(\mathrm{II})$. Experimental conditions: $2 \times 10^{-4} \mathrm{~mol} / \mathrm{dm}^{3}$ of $\mathrm{KMnO}_{4}, 1.5 \times 10^{-4} \mathrm{~mol} / \mathrm{dm}^{3}$ of 4 OHcoum., $5 \mathrm{ng} / \mathrm{cm}^{3}$ of $\mathrm{Co}(\mathrm{II})$. (•)-catalytic reaction, $(\bullet)$-noncatalytic reaction.

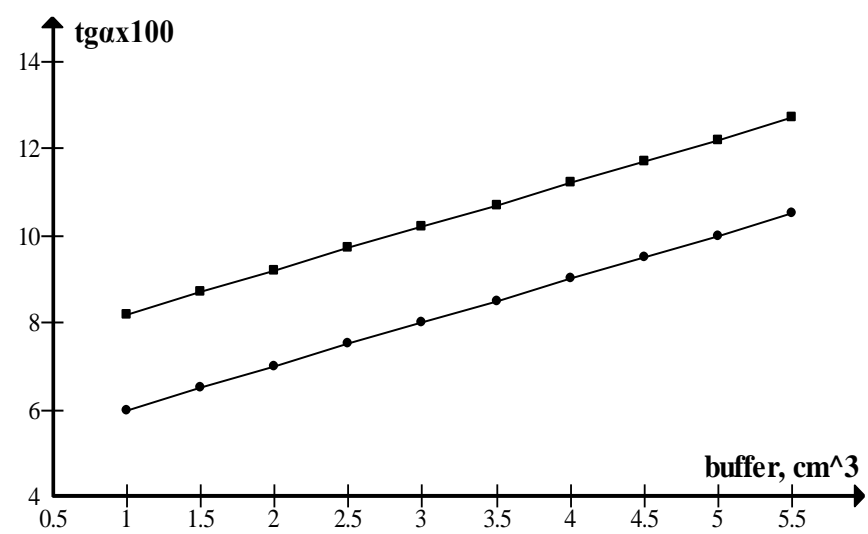

Figure 2.Effect of volume of acetate buffer on determination of $\mathrm{Co}(\mathrm{II})$. Experimental conditions: $2 \times 10^{-4} \mathrm{~mol} / \mathrm{dm}^{3}$ of $\mathrm{KMnO}_{4}$, $1.5 \times 10^{-4} \mathrm{~mol} / \mathrm{dm}^{3}$ of $4-\mathrm{OHcoum} ., 5 \mathrm{ng} / \mathrm{cm}^{3}$ of $\mathrm{Co}(\mathrm{II}) .(\cdot)$-catalytic reaction, $(\bullet)$-non-catalytic reaction. 
The dependence of the volume of acetate buffer on the reaction rate was studied in the range of 1.0 to $5.5 \mathrm{~cm}^{3}$. The results are presented in Figure 2. In this interval both reactions show the first order dependence of the volume of acetate buffer. The concentration of acetate buffer: $6.5 \times 10^{-2} \mathrm{~mol} / \mathrm{dm}^{3} \mathrm{CH}_{3} \mathrm{COOH}$, $7.3 \times 10^{-3} \mathrm{~mol} / \mathrm{dm}^{3}$ acetate ion chose as optimum concentration which respond the volume of $2.5 \mathrm{~cm}^{3}$ of acetate buffer. At higher concentration the rates of the catalytic and non-catalytic reaction accelerate.

The effect of 4-hydroxycoumarine concentration on the reaction rate was investigated in the concentration range of $5 \times 10^{-5}$ to $2.5 \times 10^{-4} \mathrm{~mol} / \mathrm{dm}^{3}$ (Figure 3 ).

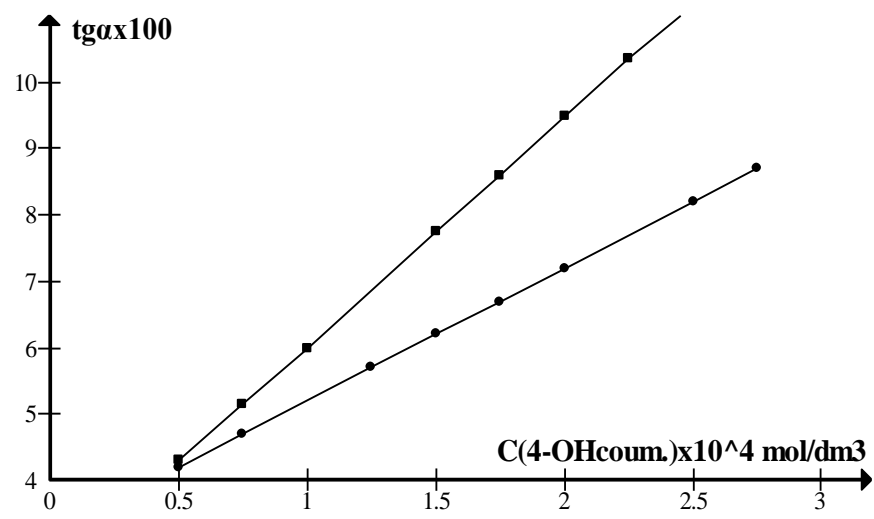

Figure 3. Effect of 4-OHcoum. concentration on determination of $\mathrm{Co}$ (II). Experimental conditions: $2 \times 10^{-4} \mathrm{~mol} / \mathrm{dm}^{3}$ of $\mathrm{KMnO}_{4}$, $5 \mathrm{ng} / \mathrm{cm}^{3}$ of $\mathrm{Co}(\mathrm{II}), \mathrm{pH}=3.8$. (•)-catalytic reaction, (•)-noncatalytic reaction.

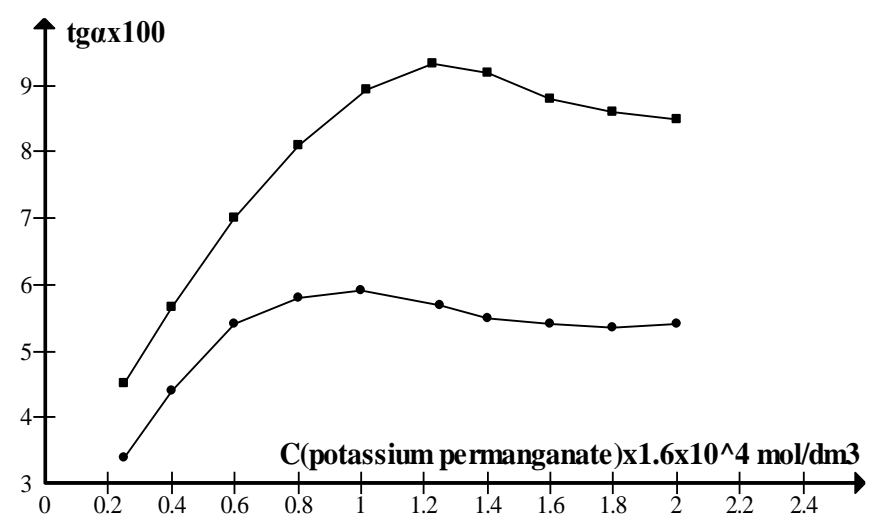

Figure 4.Effect of $\mathrm{KMnO}_{4}$ concentration on determination of $\mathrm{Co}(\mathrm{II})$. Experimental conditions: $1.5 \times 10^{-4} \mathrm{~mol} / \mathrm{dm}^{3}$ of $4-$ OHcoum., $5 \mathrm{ng} / \mathrm{cm}^{3}$ of $\mathrm{Co}(\mathrm{II}), \mathrm{pH}=3.8$. (•)-catalytic reaction, (•)non-catalytic reaction.

The catalytic and non-catalytic reactions were of the first order with respect to the concentration of 4-hydroxycoumarine. For further work a concentration of 4-hydroxycoumarine of $1.5 \times 10^{-4} \mathrm{~mol} / \mathrm{dm}^{3}$ was selected as the optimum concentration. At higher concentration of 4-hydroxycoumarine abcorbance significaully increased when the error of spectrophotometric measurement becomes higher (area of Beer's law validity).
The effect of oxidant concentration on the reaction rate was also investigated. The results are illustrated in Fig. 4. The relationship between the concentration of $\mathrm{KMnO}_{4}$ and the reaction rate was complex. The reaction order depending on $\mathrm{KMnO}_{4}$ concentration within the studied concentration of $\mathrm{KMnO}_{4}$. For further work a concentration of $2 \times 10^{-4} \mathrm{~mol} / \mathrm{dm}^{3}$ of $\mathrm{KMnO}_{4}$ was chosen. At higher concentration of $2 \times 10^{-4} \mathrm{~mol} / \mathrm{dm}^{3}$ leads to the formation of insoluble reducing the product of $\mathrm{KMnO}_{4}$ adding the problem of contamination the cell of the photometer.

\section{Calibration graph}

For the optimal conditions described above $\left(\mathrm{pH}=3.8 ; \mathrm{C}_{4}\right.$ OHcoum $=1.5 \times 10^{-4} \mathrm{~mol} / \mathrm{dm}^{3} ; \mathrm{C}_{\mathrm{KMnO} 4}=2 \times 10^{-4} \mathrm{~mol} / \mathrm{dm}^{3}$ ) a calibration graph was constructed at two different temperatures at $25 \pm 0.1^{\circ} \mathrm{C}$ and $30 \pm 0.1^{\circ} \mathrm{C}$. A Co(II) concentration under optimum conditions was varied from $0.5 \mathrm{ng} / \mathrm{cm}^{3}$ to $4 \mathrm{ng} / \mathrm{cm}^{3}$.

Figure 5 shows the corresponding calibration graph, which were used for determination of $\mathrm{Co}$ (II) concentration in the interval mentioned. The slopes of the calibration lines (1) and (2) were very similar, however the temperature of $25 \pm 0.1^{\circ} \mathrm{C}$ is recommended as appropriated.

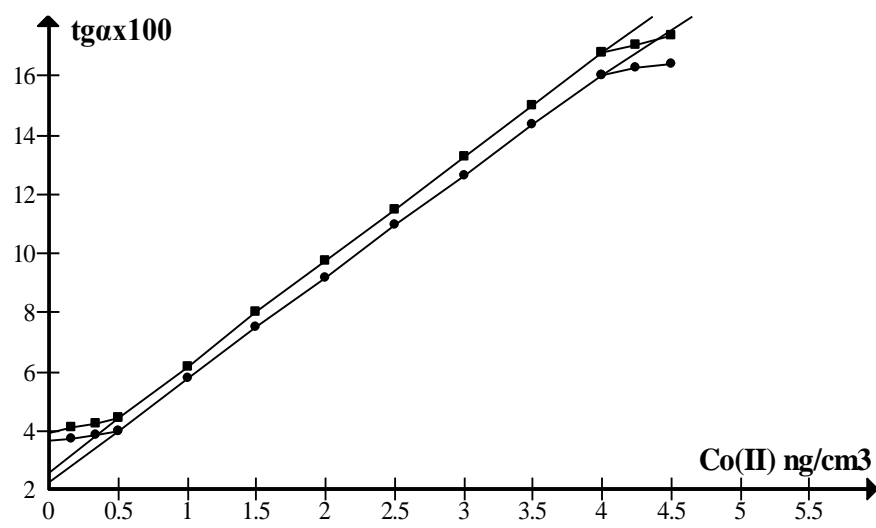

Figure 5.Effect of $\mathrm{Co}$ (II) concentration on the reaction rate Experimental conditions: $2 \times 10^{-4} \mathrm{~mol} / \mathrm{dm}^{3}$ of $\mathrm{KMnO}_{4}, 1.5 \times 10^{-4}$ $\mathrm{mol} / \mathrm{dm}^{3}$ of 4 -OHcoum., $\mathrm{pH}=3.8$. ( $\bullet$-)-temperature $25 \pm 0.1^{\circ} \mathrm{C},(\cdot)$ temperature $30 \pm 0.1^{\circ} \mathrm{C}$

The unknown concentration of Co(II) was determined using the following equations which were obtained by the least-squares method:

$$
\mathrm{C}_{\mathrm{Co}(\mathrm{II})}=(\operatorname{tg} \alpha-0.026) / 0.0346\left(\mathrm{ng} / \mathrm{cm}^{3}\right)
$$

The following kinetic equations were deduced on the basis of the graphic correlations obtained for the investigated catalytic and non-catalytic reactions (at constant $\mathrm{pH}$ ).

For the catalytic reaction:

$$
-\mathrm{dc} / \mathrm{dt}=\mathrm{k}_{1} \times \mathrm{C}_{\mathrm{KMnO}_{4}}^{\mathrm{m}} \times \mathrm{C}_{4-\mathrm{OHcoum}} \times \mathrm{C}_{\mathrm{Co}(\mathrm{II})}
$$

where $\mathrm{m}$ is a variable, $\mathrm{k}_{1}$ is a catalytic reaction rate constant.

For the non-catalytic reaction: 


$$
-\mathrm{dc} / \mathrm{dt}=\mathrm{k}_{0} \times \mathrm{C}^{\mathrm{p}} \mathrm{KMnO}_{4} \times \mathrm{C}_{4-\mathrm{OHcoum}}
$$

where $\mathrm{p}$ is a variable, $\mathrm{k}_{0}$ is non-catalytic reaction rate constant

Limit of detection (LOD) of the method was calculated as $(3 \sigma / S)$ is $0.0867 \mathrm{ng} / \mathrm{cm}^{3}$ and limit of quantification $(10 \sigma / S)$ is $0.289 \mathrm{ng} / \mathrm{cm}^{3}$, with coefficient of determination $\left(\mathrm{R}^{2}\right)$ of 0.9998 .

\section{Accuracy and precision}

Four sets of working solutions with different concentrations of $\mathrm{Co}$ (II) were analyzed under the optimum conditions using a differential variant of the tangent method.

The results for estimated precision and accuracy are summarized in Table 1. The relative standard deviation ranged from $2.60 \%$ to $6.25 \%$ for $\mathrm{Co}$ (II) concentration range $3-0.6$ $\mathrm{ng} / \mathrm{cm}^{3}$.

Table 1. Accuracy and precision of Co(II) determination

\begin{tabular}{|c|c|c|c|c|}
\hline $\begin{array}{c}\text { Taken }(\mu) \\
\left(\mathrm{ng} / \mathrm{cm}^{3}\right)\end{array}$ & $\begin{array}{c}\text { Found }(\bar{x}) \\
\left(\mathrm{ng} / \mathrm{cm}^{3}\right)\end{array}$ & $\mathrm{n}$ & $\begin{array}{c}\mathrm{RSD} \\
(\%)\end{array}$ & $\overline{(x-\mu) / \mu * 100}$ \\
\hline 0.60 & $0.64 \pm 0.04$ & 5 & 6.25 & 6.60 \\
\hline 1.00 & $1.02 \pm 0.05$ & 5 & 4.90 & 1.50 \\
\hline 2.00 & $2.02 \pm 0.05$ & 5 & 2.48 & 1.00 \\
\hline 3.00 & $3.07 \pm 0.08$ & 5 & 2.60 & 2.33 \\
\hline
\end{tabular}

$\bar{x}$-mean value \pm standard deviation; $\mu$-true value; RSD-relative standard deviation; $(\bar{x}-\mu) / \mu * 100$-accuracy

\section{Interference study}

To study the selectivity of the method we undertook a systematic study of the effect of foreign ions on the catalytic reaction rate, under the optimal conditions mentioned above, at a constant concentration of $\mathrm{Co}$ (II) $\left(4 \mathrm{ng} / \mathrm{cm}^{3}\right)$. Each ion was added in eight known concentration ratios $\left(10^{5}: 1,10^{4}: 1,10^{3}: 1,10^{2}: 1\right.$, $10: 1, \quad 1: 1, \quad 10^{-1}: 1$ and $\left.10^{-2}: 1\right)$ against the constant $\mathrm{Co}(\mathrm{II})$ concentration of $4 \mathrm{ng} / \mathrm{cm}^{3}$.

The presence of $\mathrm{K}^{+}$and $\mathrm{Cl}^{-}$, in the ratio $10^{5}: 1, \mathrm{NH}_{4}^{+}$and $\mathrm{SO}_{4}{ }^{2-}$, in the ratio $10^{4}: 1, \mathrm{Mg}^{2+}, \mathrm{Cu}^{2+}, \mathrm{Mn}^{2+}, \mathrm{I}^{-}$, in the ratio $10^{3}: 1$, $\mathrm{Ca}^{2+}, \mathrm{Ba}^{2+}, \mathrm{Sr}^{2+}, \mathrm{Pb}^{2+}, \mathrm{Cd}^{2+}, \mathrm{Sn}^{2+}$, in the ratio $10^{2}: 1$ has practically no influence on the reaction rate. The presence of $\mathrm{Fe}^{3+}$, in the ratio $10^{-2}: 1, \mathrm{Zn}^{2+}$, in the ratio $10^{-1}: 1$ and $\mathrm{Ni}^{2+}$, in the ratio 10:1 further catalyzes the determination of cobalt. $\mathrm{SCN}^{-}$, $\mathrm{PO}_{4}{ }^{3-}, \mathrm{C}_{2} \mathrm{O}_{4}{ }^{2-}$, in the ratio 10:1 have a slight inhibiting effect. The results reveal that proposed method for $\mathrm{Co}(\mathrm{II})$ determination have a very good selectivity.

\section{CONCLUSION}

Development of the fast, simple, inexpensive and applicable kinetic-spectrophotometric method for the determination of $\mathrm{Co}(\mathrm{II})$ traces were reported in this paper. The method has very low detection limit, which falls within the range of more sensitive methods for Co(II) determination. Therefore, this method could be appropriate for the fast monitoring of traces amounts of $\mathrm{Co}$ (II) in different samples, with available and cheap chemicals and instrumentation.

\section{REFERENCES}

Bahram, M., \& Khezri, S. 2012. Multivariate optimization of cloud point extraction for the simultaneous spectrophotometric determination of cobalt and nickel in water samples. Anal. Methods, 4(2), pp. 384-393. doi:10.1039/c2ay05527a

Ghasemi, J., Niazi, A., \& Safavi, A. 2001. Simultaneous catalytic determination of cobalt, nickel and cooper using resazurine sulfide reaction and partial square $s$ calibration method. Analytical Letters, 34(8), pp. 1389-1399. doi:10.1081/al-100104162

Jiang, H., Qin, Y., \& Hu, B. 2008. Dispersive liquid phase microextraction (DLPME) combined with graphite furnace atomic absorption spectrometry (GFAAS) for determination of trace $\mathrm{Co}$ and $\mathrm{Ni}$ in environmental water and rice samples. Talanta, 74(5), pp. 1160-1165. doi:10.1016/j.talanta.2007.08.022

Juvonen, R., Lakomaa, T., \& Soikkeli, L. 2002. Determination of gold and the platinum group elements in geological samples by ICP-MS after nickel sulphide fire assay: difficulties encountered with different types of geological samples. Talanta, 58(3), pp. 595-603. doi:10.1016/s00399140(02)00330-2

Kamble, G.S., Ghare, A.A., Kolekar, S.S., Han, S.H., \& Anuse, M.A. 2011. Development of an reliable analytical method for synergistic extractive spectrophotometric determination of cobalt(II) from alloys and nano composite samples by using chromogenic chelating ligand. Spectrochimica Acta Part A: Molecular and Biomolecular Spectroscopy, 84(1), pp. 117 124. doi:10.1016/j.saa.2011.09.015

Kiran, B.V., Dubey, S., \& Rao, B.S. 2012. KineticSpectrphotometric Determination of $\mathrm{Co}$ (II) in Vegetable Samples by Using indigo-carmine. International Journal of Pharmaceutical Research, 4(3), pp. 64-68.

Li, Y. 1998. Catalytic kinetic spectrophotometric determination of trace cobalt(II). Huaxue Fence, 34, pp. 408-409.

Medina-Escriche, J., Hernández-Llorens, M.L., Llobat-Estelles, M., \& Sevillano-Cabeza, A. 1987. Determination of vitamin B12 as cobalt by use of a catalytic spectrophotometric method. The Analyst, 112(3), pp. 309-311. doi:10.1039/an9871200309

Mikuła, B., \& Puzio, B. 2007. Determination of trace metals by ICP-OES in plant materials after preconcentration of 1,10 phenanthroline complexes on activated carbon. Talanta, 71(1), pp. 136-140. doi:10.1016/j.talanta.2006.03.041

Mitić, S.S., Micić, R.J., \& Budimir, M.V. 2009. Highly Sensitive Determination of Traces of $\mathrm{Co}(\mathrm{II})$ in Pharmaceutical and Urine Samples Using Kinetic-Spectrophotometric Method. Analytical Letters, 42(7), pp. 935-947. doi:10.1080/00032710902809017

Naseri, A., Bahram, M., \& Mabhooti, M. 2011. A second-order standard addition method based on the data treatment by calculation of variation matrix of kinetic systems analyzed by MCR-ALS. Journal of the Brazilian Chemical 
Society, 22(11), pp. 2206-2215. doi:10.1590/s010350532011001100026

Safavi, A., Abdollahi, H., Hormozi, N.M.R., \& Kamali, R. 2004. Cloud point extraction, preconcentration and simultaneous spectrophotometric determination of nickel and cobalt in water samples. Spectrochimica Acta Part A: Molecular and Biomolecular Spectroscopy, 60(12), pp. 2897-2901. doi:10.1016/j.saa.2004.02.001

Safavi, A., Abdollahi, H., \& Nezhad, M.R.H. 2002. Indirect kinetic spectrophotometric determination of Co (II) based on the reaction with iron (III) in the presence of 1,10phenantroline. Spectroscopy Letters, 35(5), pp. 681-688. doi:10.1081/sl-120014939

Suleiman, J.S., Hu, B., Xulli, P., Huang, C., \& Jinag, Z. 2007. Nanometer sized zirconium dioxide microcolumn separation/preconcentration of trace metals and their determinatin by ICP-OES in environmental samples and biological samples. Microc. Acta, 159(3-4), pp. 379-385.

Wang, X. 2003. Catalytic spectrophotometric etermination of trace cobalt based on oxidation of alizarin green by H2O2. Yejin Fenxi, 23, pp. 17-18. 